\title{
Islamic Education Based on Multiculturalism through Experiential Learning Approach at University of Muhammadiyah Malang
}

\author{
Moh. Nurhakim \\ University of Muhammadiyah Malang, Indonesia \\ nurhakimenator@gmail.com
}

\begin{abstract}
This research focused on the primary elements of multicultural based-religion education at University of Muhammadiah Malang, namely (1) Philosophical basic concept of education; (2) Basic concept of curriculum base; (3) Class management arrangement and the creation of educational environment. This case research used a Qualitative approach; the data was collected by using observation technique, in-depth interview, and documentation. The findings of the research are as follows : (1) theoretically, the multicultural paradigms in this university is understood in the limitation of the needs to build cross religion understanding and tolerance. $A$ multicultural based on religion education model whose concept is taken from this case is functioned to establish our own beliefs as well as to understand other people religion without being trapped into what so called "negative truth claim". (2) A learning approach which focuses on the involvement in the learning and giving live experience process with cross religion students can create an interest and dynamic of learning, as well as grow the understanding between multi religion students.
\end{abstract}

Keyword: learning, multicultural, religion

\section{INTRODUCTION}

Why does social tension and conflict related to religion cases becomes endless issues in Indonesia; but a conflict often occurs lately when the Indonesian nation is reforming its socio-political system into a democratic and civilized one? The results of an anthropological study made by Parsudi Suparlan [1] shows that although the Indonesian Nation is known for being multiculture, for its ethnique and religion diversity, up to now, cultural and development strategy and cultural "uniformation" is occuring authoritatively in almost all aspects of life. This in turn makes Indonesia unready to face various types of "new" cultural diversities" as a

In order to face the reality, namely the "new" culture, a nation does not merely understand and accept the "diversity" of reality, or even deny it, but also intensively involves in it, including the willingness to manage the implications either at academic-theoretical work or in daily practical levels. In this context, the education, especially religious education, is expected to play an important role as the most effective entrance for any effort to the "civilization" of diversity awareness which in turns may avoid the potential social-religious tension, violation and conflict. This perspective is reinforced by recent findings of studies at University of Muhammadiyah Malang. They show that a radical and moderate tendency shown by the students' attitudes towards their religion among other is caused by types of religious education approaches given to them and the intensity of contact with their religion movement when they were studying in higher education [2].

Although in this context the role of religious education in higher education is centralistic, it is assumed that the approaches and methods adopted are not interesting, since the lecturers, according to the study, only depend on doctrinal approach and lecturing method. Although discussion and question-and answer methods at a certain extent were also employed, the students felt that the learning materials were heavy. The students thought that in the lectures they merely receive information or knowledge, without any relevancy, even direct involvement with the discussed problems or daily realities, including those of the diversity of cultures and people they are facing in their daily lives.

Therefore, one of important preliminary steps in developing the religious education is to build a theoretical model of multiculturalism-based religion education and an approach to learning religion that may give the students experiences about and direct involvement in problems they are facing, especially those concerning the diversity of culture and religion.

\section{METHOD}

Based on the main perspectives above, in this present study an analysis of a theoretical model of multiculturalism-based religion education is made. Moreover, the way the model was practiced by using an experiential learning approach in University of Muhammadiyah Malang, which has multi-religion students background, is also explored. Therefore, the research focus may be formulated as follows. (1) What is the philosophical foundation of the religious education employed for the study of religion for multi-religion students? (2) What is the basic concept of the religious education curriculum designed to give understanding 
among multi-religion students? (3) What is the classroom management arrangement and an educational environment that may draw the students' interest and may create dynamism and understanding among multireligion students

\section{Multiculturalism and Experiential Learning Approach Concept}

How is the theoretical relationship between multiculturalism and religion education? The basic concept of multiculturalism in relation to religion adopted in this study is a acknowledgment to the existence of other religions and its implications such as acknowledgement and respects to the rights of the followers in expressing and practicing their belief. Therefore, attitudes of tolerance, respect, cooperation and dialogic relation among followers of different religions become a need as the realization of acknowledgement to other religions. This thesis is in line with the opinion proposed by Muhammad Ali about the concept of 'pluralist-multiculturalism', meaning the religion understanding that respects religion diversity and cultural expressions (Muhammad Ali, 2003: xviii). On the other hand, it is necessary to emphasize that an evaluation on right-wrong matters about other religions should be placed in another study, namely theological study.

To support the second thesis, concerning with the religious education based on some recent studies, it can be stated that among university students, it is necessary to give them the understanding that may build an interreligion agreement. In order to reach such an agreement, it should not reduce the students' belief in their religion even into a statement that "all religions are right" [3]. Therefore, to the best of my knowledge, the multiculturalism-based religious education paradigm adopted in this present study will not lead to a view that "all religions are right".

It is the theoretical base that will be developed in this study. It means that this study tried to build an alternative model of multiculturalism-based religion education using an approach that may create an environment that enables students with multi-religion backgrounds to find their own pluralistic life (read: experiential learning).

Carl Rogers, a prominent figure in humanism, classifies two types of learning, namely cognitive and experience. The former refers to academic knowledge considered as less meaningful, while the latter refers to applicative knowledge considered to be more usefull. The difference lies on how experiential learning leads to individual needs and desires. The quality of experiential learning is shown by personal involvement, initiative from the individual, evaluation from the individual and influences as internalized in the individual him-herself [4].

Every person possesses a natural tendency to learn. Therefore, the teacher's role is just a facilitator, namely to (1) create a climate positive for the learning process; (2) clarify the purpose of the learning process and of individuals; (3) organize and create learning sources; (4) keep the balance between intellectual and emotional components of learning and (5) share feelings and thoughts with individuals without any [5].

It can be realized if the learner (1) paticipates actively in the whole learning process and is able to control himself or herself; (2) is especially faced with direct social, practical, personal or research problems; (3) is making self-evaluation which is important to measure his or her development and success. Concerning with the religious learning for university students, it is more appropriate to use andragogical theories with a learning approach from one' self-experiences than to use a lecturing approach where the students merely listen to the teacher.

\section{RESULT}

The data were focused on three research problems: (1) philosophical basic concept of education; (2) basic concept of the curriculum; (3) classroom management design, and the creation of educational environment at University of Muhammadiyah Malang.

\section{The Basic Philosophy of the Religion Education}

University of Muhammadiyah Malang as a Higher Education Institution affiliated to one of Islamic mass organizations does not only accepts moslem students but also (some) non moslem students. The reason this institution accepts students with various backgrounds is to grow a multiculturalism-based educational principle.

This concept, hopefully, creates an educational system that holds high values or humanistic attitudes, tolerance, respect and honor with one another among the civitas academica. Moreover he states that the concept of multicultural education is closely related to ethics, especially social ethics, since the essence of multiculturalism is "how one may understand, accept and work together with other persons regardless of all existing differences. Therefore, efforts to facilitate the development of attitudes reflecting such understanding, acceptance and cooperation may be done through the building of ethic that may raise some awarenes among individuals".

The concept of multiculturalism as a learning approach may create various materials in the religion course intended to implant tolerance values. According to his perspective, this approach is able to appreciate the student diversity and also to promote some awareness of the diversity.

Such a kind of model is always made use of by Syamsul every time he is teaching the religion course in UMM. Especially, in a class where non moslem students exist, he always gives maximum explanations about general religion materials which can be accepted by any students. For particular matters, for example faith and religious service, of course it is difficult to have such common understanding. 


\section{The Basic Concept of the Curriculum}

In this religious education, the UMM institution does not merely give learning materials on the teachings of a religion but also on knowledge about other religions through comparisons and studies of religions specially intended for the students of Islamic Religion Faculty. According to Faridi, a lecturer of Studies of Religions, the objective is to provide the students with understanding about various religions existing in the world. It is hoped that the students who have joined in this course may have some awareness of the importance of religiosity tolerance attitudes.

The concept of religiosity tolerance in interfaith students is a method to create the harmony among people who live in heteregenous environment. In Islam, this concept is intended to arrange a social relation system among the people. Islam, Faridi said, is a religion that respects and holds high interfaith tolerance attitudes.

The seriousness of the UMM in giving the study of religions course is shown by inviting some leaders of religions, for example in 2003, the Islamic Religion Faculty invited a resource person, the clergyman Suwignyo, M.Si from Gereja Jawi Wetan (GKJW), Malang. This activity was intended to give knowledge to the students about Christian as a part of series in learning materials of Studies of Religions.

Hopefully the students could get knowledge about other religions and they might have high commitment to their religion and also have respect, appreciation and tolerance to other religions.

\section{Classroom Management and Creation of Environment}

The design of the multicultural class does not only train the students to develop some awarenss of tolerance attitude, but also demands the leacturers to master the material coruse from various perspectives or understandings related to religion. A students felt that teaching interfaith students gave him certain challenges, namely he should master materials of the teachings of Islam and also be familiar with teachings of other religions in order to be able to compare them.

In the religion learning process using an experiential learning approach, students play more active individually. Each class contained 30 up to 40 students with various (heterogeneous) backgrounds. They were guided by three teaching assistants and three instructors. Each instructor taught a material according to his expertise in each class.

The teaching asistants were taken from seniour students, while the instructors are lecturers of religion at UMM. They adopted an experiential learning-based religion learning model and they served as facilitators, namely facilitating various activities held by the students in order to produce active and dynamic learning processes.

Students said that in ritual religious activities, non moslem students were not asked to join in, although the activities were included in the agenda of the P2KK.
However, when moslem students were practicing their services, there were many non moslem students who saw the ritual activities and they were allowed to ask questions.

\section{CONCLUSIONS}

The religious education in the University of Muhammadiyah in a certain extent gives understanding to the students about other religions in order to make them to have tolerant, dialogic and cooperative attitudes needed by interfaith students.

In formulating the religion education curriculum, the formulation and weight are different, they introduce tolerance principles inter-religion followers and include knowledge on other religions. Then, discussions on tolerance are included in the text-books or modules, and lecturers with authority in the field of certain religion and interfaith is invited.

In order to hold interesting and dynamic lectures, learning methods such as FGD (Focused Group Discussion), Games, Case Study and Participation Research, besides lecturing methos, are employed. And, concerning with creating an environment specifically designed to give life experiences among cross-religions students in UMM, the case is included into the P2KK program.

From the findings in point 1 to 3 , theoretically it can be concluded as a model that (1) the multiculturalism paradigm in the University of Muhammadiyah Malang can be understood as a need to build intefaith agreement and tolerance. A multiculturalism-based religion education model taken from this case is to implant religion faith itself while understanding other people's religions without being trapped into what is called "negative truth claiming"; (2) the learning approach oriented to involvement in the learning process and to give inter-student life experiences may create an interest and dynamism in learning, and may implant agreements among multi-religion students

\section{REFERENCES}

[1] Adeney, Bernard T. Strange Virtues: Ethics in a Multicultural World, InterVarsity Press, Downers Grove, Illinois. 1995.

[2] Arifin, Syamsul. Praktek Multikultural Berbasis Kearifan Lokal sebagai Perekat Sosial dalam Masyarakat Berbeda Agama di Pedesaan Batu, Laporan Penelitian, UMM, Malang. 2005.

[3]. Bungin, Burhan (ed). Metodologi Penelitian Kualitatif, Raja Grafindo, Jakarta. 2001.

[4] Diknas RI. Undang-Undang Republik Indonesia Nomor 20 Tahun 2003 tentang Sistem Pendidikan Nasional, Biro Hukum dan Organisasi Diknas, Jakarta. 2003.

[5] Giddens, Anthony. Sociology, Polity Press, Cambridge, UK. 1996. 
[6] Seifuddin, Ahmad Fedyani. Kegamangan Multikultural di Indonesia, Kompas, akses 21 Januari 2006.

[7] Suparlan, Parsudi. Menuju Masyarakat Indonesia yang Multikultural,akses 1 Maret 2006.

[8] Suriasumantri, Jujun S. Tradisi Baru Penelitian Agama Islam Tinjauan Antardisiplin Ilmu, Pusjarlit dan Penerbit Nusa, Jakarta. 1998.

[9] Nurhakim, Moh.Studi Islam di UMM Paradigma, Sejarah dan Kelembagaannya, Laporan Penelitian UMM, Malang. 2005.

[10] Pedersen, Paul B. 110 Experiences for Multicultural Learning, American Psychological Association, Washington DC. 2004.
[11] Porter s, Bobbi dan Mike Hernacki. Quantum Learning Membiasakan Belajar Nyaman dan Menyenangkan,cet. XVII, 2003, Kaifa, Bandung. 2003.

[12] Tilaar, H.A.R. Multikultural Tantangantantangan Global Masa Depan dalam Transformasi Pendidikan Nasional, Grasindo, Jakarta. 2004.

[13] Tenant, M. Psycology and Adult Learning, Second Edition, Rouladge, London. 1997.

[14] Tim Dosen AIK.Modul Pelatihan Pengembangan Kepribadian dan Kepemimpinan Mahasiswa Baru, Bahan Pelatihan UMM, Malang. 2005. 